\title{
A Practical Approach for Teaching Finite Element Analysis for Senior Undergraduate Mechanical Engineering Students
}

\author{
Khaled S. Al-Athel \\ Mechanical Engineering Department \\ King Fahd University of Petroleum \& Minerals \\ Dhahran, Saudi Arabia \\ kathel@kfupm.edu.sa
}

\begin{abstract}
This paper discusses the common trends in teaching finite element analysis (FEA) in mechanical engineering programs and then presents a fresh look into a practical approach to teaching FEA. A case study on teaching FEA at King Fahd University of Petroleum \& Minerals (KFUPM) is presented by discussing the syllabus, course structure, nature of exams, and the lab work.
\end{abstract}

Keywords: Finite element analysis, teaching, mechanical engineering, undergraduate students

\section{INTRODUCTION}

Finite Element Analysis (FEA) is one of the subjects where one would find some variations in the way it is taught in mechanical engineering departments. Most schools started teaching FEA at the graduate level due to the nature of the subject as it is heavily based on mathematics and programming. FEA taught at the graduate level usually focuses more on the theory and enable students to develop skills to write their own programs or codes rather than utilize a commercial software. In addition, such courses usually are based on research topics instead of practical engineering applications [1].

This was mostly true till the 90 s where many commercial software became available and the need to write an FEA code became less necessary. With that, many mechanical engineering departments started offering FEA at the undergraduate level as a senior elective course in addition to keeping graduate level FEA with the same objectives. Some engineering programs integrate some FEA aspects into engineering courses (structural mechanics, vibration, etc.) [1, 2]. This works well as an introduction to FEA, but without a dedicated course to FEA, students will not have the minimum needed theoretical background and hands-on practice on commercial codes.

Shaikh [3] presented a study on the role of introducing an FE commercial code in teaching an undergraduate FE course. This obviously had a positive impact but course still was based on theory and had the same simply supported beam project for all students. Zhuge and Mills [4] presented a project-based approach to teaching FEA for undergraduate students. The course covers the usually FE theory but focuses more on projects where students could pick a practical topic of their interest and go in detailed analysis using FEA. A simple module was presented by Hossain [5] but for a quarter module (instead of the traditional fall/winter semesters). This restricted the course to simple examples using the FE software due to the lack of time. Moazed et al. [6] presented a different course structure that is based heavily on lab session and less on theory. The course was offered for Mechanical Engineering Technology (BMET) program, hence the course being more practical. The course had two lab sessions per week, in addition to the lectures, and covered topics in structural mechanics, thermal analysis, and dynamics. The course has an excellent model but lacks in theory, as it is not intended for ME B.Sc.

In this paper, a practical approach to teaching FEA to undergraduate students is presented with details on the topics covered, course structure, and samples from exams and projects. The approach presented covers the minimum needed theory for mechanical engineers while focusing heavily on utilizing commercial FE software for engineering design and analysis.

\section{MinIMUM FE THEORY NEEDED}

Usually, the amount of theoretical topics needs to be covered in the course is what dictates how far someone can go in covering practical FE examples using FE commercial software. Table 1 lists the common theoretical topics usually covered in undergraduate FEA courses and discusses whether they should be covered or not (from the authors' perspective).

One of the main theoretical aspects of FEA is the derivation of the stiffness matrix and matrix equations. There are many different approaches used, commonly the direct stiffness method, potential energy approach, Galerkin's residual method. These methods serve the same purpose, regardless of the advantages/disadvantages in applying them. Graduate FEA courses might require students to learn how to derive their own elements to serve a certain behavior, and therefore they need to learn how to derive such matrices and equations. Undergraduate engineering students only need to learn how the equations were derived in order to understand how to link them with the physical behavior. Therefore, the direct stiffness method serves that purpose and is very easy for students to follow and understand. That being said, as the course moves 
from 1D elements to $2 \mathrm{D}$ and $3 \mathrm{D}$ elements, the direct stiffness method becomes tedious and lengthy, hence the need for one of the advanced methods. The potential energy approach also serves that purpose and is easy to follow and understand. Its only drawback is that it applies only to linear analysis. This is not an issue as the majority of FEA undergraduate course do not cover nonlinear topics (which is suggested). There is no need for undergraduate students to learn all the methods. The direct stiffness method is sufficient for lectures and HWs, whereas the potential energy approach is useful for more advanced topics to be covered in the lectures.

TABLE I. Theoretical topics to be covered in an FE course

\begin{tabular}{|c|c|}
\hline Topics & Comments \\
\hline $\begin{array}{l}\text { Spring, Bar (Truss) } \\
\text { Elements }\end{array}$ & Covered with direct stiffness method \\
\hline Beam Elements & $\begin{array}{l}\text { Covered with direct stiffness method and } \\
\text { potential energy }\end{array}$ \\
\hline Frames and Grids & Covered \\
\hline $\begin{array}{l}\text { Plane Stress \& Plane Strain } \\
\text { Using Rectangular } \\
\text { elements } \\
\end{array}$ & Covered with potential energy \\
\hline $\begin{array}{c}\text { Plane Stress \& Plane Strain } \\
\text { Using Linear-Strain } \\
\text { Triangle (LST) }\end{array}$ & Covered \\
\hline Axisymmetric Elements & Covered with potential energy \\
\hline $\begin{array}{l}\text { Isoparametric } \\
\text { Formulations }\end{array}$ & $\begin{array}{l}\text { Not covered. This is only useful for code writing } \\
\text { and not useful for practical engineers when } \\
\text { using commercial codes }\end{array}$ \\
\hline 3D FEA & $\begin{array}{l}\text { Not covered. The formulation is very similar to } \\
2 \mathrm{D} \text { but very lengthy for hand calculations. } 3 \mathrm{D} \\
\text { can be covered in practical examples in lab } \\
\text { sessions }\end{array}$ \\
\hline Plates \& Shells & $\begin{array}{l}\text { Not covered. The theory is more advanced and } \\
\text { will require substantial time from the lecture } \\
\text { hours to cover it with adequate number of } \\
\text { examples. It can be covered in practical } \\
\text { examples in lab sessions }\end{array}$ \\
\hline Heat Transfer & $\begin{array}{l}\text { Covered without details on stiffness equation } \\
\text { derivation. The approach is already covered in } \\
\text { the mechanical part of the course. This could be } \\
\text { given as a read assignment for students if the } \\
\text { instructor deemed important. }\end{array}$ \\
\hline Thermal Analysis & Covered without derivation. \\
\hline Structural Dynamics & $\begin{array}{l}\text { This depends on the independent ME programs. } \\
\text { If structural dynamics or vibration is a core } \\
\text { course, then this could be covered. If not, then it } \\
\text { should not be covered, as it would require } \\
\text { teaching the basic vibration theory in addition to } \\
\text { the FEA theory. This could be considered as a } \\
\text { suggestion for additional topics. }\end{array}$ \\
\hline Additional Topics & $\begin{array}{l}\text { Every mechanical engineering department } \\
\text { should have additional topics based on the } \\
\text { industrial and research topics that are considered } \\
\text { relevant to the department and the region where } \\
\text { the university is located. } \\
\text { Examples for such topics: } \\
\text { - Coatings } \\
\text { - Composite materials } \\
\text { - Piezo electric materials (PZTs) } \\
\text { - Introduction to CFD }\end{array}$ \\
\hline
\end{tabular}

\section{SUGGESTED PRACTICAL APPROACH FOR TEACHING FEA}

The suggested practical way to teach FEA for undergraduate mechanical engineering students is to limit the theory to what is needed to understand how FE works. The rest should focus on how to utilize commercial FE software in design and analysis of practical applications. The link between the theory and practice comes from utilizing the understanding of how FE works and converting it into practical use of FE software on how to properly model the problem and apply boundary conditions (BCs) and loads (problem idealization is commonly used for to describe this).

Lab sessions should go in parallel with the suggested topics in Table I. It is important to discuss mesh dependency to students from the beginning to establish it as a regular part of the process. In addition, model validation should be done early on to teach students the concept of validation and verification of computational results. A special lab session with prepared examples should be given when going into $2 \mathrm{D}$ and $3 \mathrm{D}$ analysis to cover advanced topics such as types of symmetry, stress singularity, mesh convergence, etc.

Due to the nature of the course, hand calculations should be given in assignments, as they tend to be lengthy, while keeping the theory-based exam limited to simple theoretical discussion and short calculations. Final exam should be based on solving a practical problem including all the necessary steps in FE modeling and analysis. Lab assignments are based on the topics covered in a weekly basis. Course projects should be kept to the students to choose a topic of interest or choose a topic related to his/her capstone senior design project, or apply FEA to any other project from another course. Table II lists a suggested grading scheme. Students are encouraged to work in teams for their projects, but individually for their assignments. The course is designed such that assignment are used to test students' understanding of the FE theory, whereas the midterm is used to test the understanding of the basic concepts of FE.

TABLE II. FEA Course Grading Scheme

\begin{tabular}{|c|l|l|}
\hline Assessment & Weight & \multicolumn{1}{c|}{ Comments } \\
\hline Assignments & $25 \%$ & $\begin{array}{l}\text { Assignments are a mix of: } \\
- \text { Hand calculation problems (for lengthy problems } \\
\text { students are encouraged to use MATLAB or } \\
\text { other similar software) } \\
\text { - FE software problems. }\end{array}$ \\
\hline Project & $25 \%$ & $\begin{array}{l}\text { Students can work in groups of their choice. } \\
\text { Students should pick project topics based on: } \\
- \text { Their interests, or } \\
- \text { Their senior capstone projects, or } \\
\text { - Other courses projects }\end{array}$ \\
\hline Midterm & $20 \%$ & $\begin{array}{l}\text { Simple hand calculations, conceptual questions, } \\
\text { discussions, etc. }\end{array}$ \\
\hline Final Exam & $30 \%$ & $\begin{array}{l}\text { Practical engineering problem(s) where students } \\
\text { submit a soft copy of a report that would include: } \\
- \text { Problem idealization } \\
- \text { FE model details } \\
- \text { Requested results (figures) } \\
- \text { Results and Discussion } \\
- \text { Suggested validation approach }\end{array}$ \\
\hline
\end{tabular}




\section{CASE STUDY}

This section provides examples from when the FEA course was offered in the new structure in the fall semester 2017/2018 at the mechanical engineering department at King Fahd University of Petroleum \& Minerals. At the end, comments from the students are given to share students' perspective of the course structure. A sample home assignment including both hand calculations as well as FE software problems is given as an example to the assignment structure. A short version of the final exam problem is shown here for reference. And finally, some of the course projects are listed to highlight the how far students can reach with the suggested course structure.

\section{A. Assignment Problems}

Assignments are developed in a way that students would utilize an FE software to solve the problem and then be able to validate using hand calculations. A couple of typical assignments are listed in Table III for reference and so the reader would follow the structure suggested for the assignments. Assignments at the beginning of the course tend to have more hand calculations and less practical problems to be solved by the software as they are mostly truss and 1D beam problems. That being said, one can have practical 1D problems as the first example shown in Table I. As the course moved toward 2D and 3D problems, one can assign problems similar to examples 2 and 3 .

\section{B. Exam Problems}

As mentioned in Table II, there are two exams in this structure. The midterm is supposed to have short hand calculations and some conceptual questions. These usually the typical exams that are given in such courses. The focus here will be on the nature of the final exam using an FE software. The course is supposed to teach students the concepts of FEA to be applied to practical problems and analyzed using an FE software. Therefore, it is suggested in this structure that the final exam should be a practical problem were students would use their FE software skills to analyze it while utilizing their theoretical knowledge of FEA. Table IV lists a practical problem on thermal barrier coatings (TBCs) that was taken from an actual research [7] but simplified to for the course level and was offered in the final exam. Students are expected not only to solve the problem using the software, but include all the necessary steps that they have been doing in the lab and assignments (idealization, mesh sensitivity, validation approach, etc.)

\section{Course projects}

Students were asked from the second week to form groups of their own and choose topics (they can also work individually). Students were encouraged to utilize their capstone projects, or projects from other senior level courses. If neither is applicable, then they can choose a topic of their interest. Table $\mathrm{V}$ lists some of the projects that student worked on with sample FE results. Projects are worth $25 \%$, were $5 \%$ is evaluated by two other faculty members in a poster session, and $20 \%$ is evaluated based on the project report.
TABLE III. Examples of FEA course assignments

\begin{tabular}{|c|c|}
\hline Example & Description \\
\hline 1 & $\begin{array}{l}\text { As an engineer with background in FEA, your supervisor asked } \\
\text { you to design a beam made of ASTM A36 steel ( } E=210 \mathrm{GPa} \text { ) } \\
\text { with allowable stress of } 160 \mathrm{MPa} \text { to support the load as shown in } \\
\text { the initial design figure. An "I" shape (wide flange) beam is to be } \\
\text { used. Compare the stresses when using different W460 sections. } \\
\text { What is the safety factor of each case? Suggest one section to be } \\
\text { your final choice } \\
\text { 1. Discretize the problem using four elements (for hand } \\
\text { calculation validation). } \\
\text { 2. Show your FE model with the loads and BC. } \\
\text { 3. List the units you are using for the dimensions, load, and } \\
\text { material properties. } \\
\text { 4. Provide a table with columns for the W460 size, maximum } \sigma_{x} \text {, } \\
\text { and safety factor. }\end{array}$ \\
\hline 2 & $\begin{array}{l}\text { Stiffeners are common in engineering applications. The purpose of } \\
\text { using another material as an added beam layer, or as a stiffener, is } \\
\text { to increase certain properties or enhance the behavior, such as to } \\
\text { make the structure stiffer. Consider an aluminum beam }(E=70 \\
\text { GPa, } v=0.3) \text { with dimensions length } \mathrm{L}=200 \mathrm{~cm} \text {, width } \mathrm{W}=10 \\
\text { cm, and height } \mathrm{H}=5 \mathrm{~cm} \text {. A steel beam }(E=200 \mathrm{GPa}, v=0.3) \text { is } \\
\text { added on top of the aluminum beam with dimensions' length } \mathrm{L}= \\
\text { 200 cm, width } \mathrm{W}=10 \mathrm{~cm} \text {, and height } \mathrm{H}=2 \mathrm{~cm} \text {. The beam is } \\
\text { loaded with applied forces of } 1000 \mathrm{~N} \text { and } 2000 \mathrm{~N} \text { at the free end as } \\
\text { shown in the figure. } \\
\text { 1. Discretize the problem } \\
\text { 2. Provide mesh sensitivity analysis } \\
\text { 3. Evaluate the deflection at the tip of the aluminum beam with } \\
\text { and without the steel beam. Comment on the effect of adding } \\
\text { the thin steel beam on the deflection of the aluminum beam. } \\
\text { 4. Plot the contours of the von-Mises stress and the von Mises } \\
\text { strain and comment on the results }\end{array}$ \\
\hline & $\begin{array}{l}\text { Dimensions are given in } \\
\text { another detailed 2D figure }\end{array}$ \\
\hline 3 & $\begin{array}{l}\text { Heat sinks are used to enhance heat dissipation from electronic } \\
\text { devices. In this case study, a heat sink made of aluminum is used } \\
\text { for the study. A fan forces air over all surfaces of the heat sink } \\
\text { except for the bottom of base, where a heat flux } q^{\prime}=1000 \mathrm{~W} / \mathrm{m}^{2} \text { is } \\
\text { prescribed. The surrounding air is } 28^{\circ} \mathrm{C} \text { with a heat transfer } \\
\text { coefficient of } h=30 \mathrm{~W} /\left(\mathrm{m}^{2 \circ} \mathrm{C}\right) \text {. } \\
\text { 1. Idealize the problem } \\
\text { 2. Perform mesh sensitivity analysis } \\
\text { 3. Discuss your approach for validation of the model } \\
\text { 4. Study the steady-state and transient thermal response of the } \\
\text { heat sink }\end{array}$ \\
\hline
\end{tabular}


TABLE IV. Final exam problem

\begin{tabular}{|c|c|c|c|c|c|}
\hline Section & & & escrip & & \\
\hline Background & $\begin{array}{l}\text { Supcrallo } \\
\text { Thermal barrie } \\
\text { turbines. They } \\
\text { temperature. Th } \\
\text { as a coating for } \\
\text { top coat (TC) } \mathrm{T} \\
\text { bond coat (BC) } \\
\text { and the under } \\
\text { superalloy fron } \\
\text { temperature cor } \\
\text { develops at the } \\
\text { systems is the } \\
\text { (TGO) either } 1 \\
\text { fracture }\end{array}$ & $\begin{array}{l}\text { TBC sy } \\
\text { sas turb } \\
\text { coating } \\
\text { protect } \\
\text { ing su } \\
\text { oxidati } \\
\text { sion, a } \\
\text { op of } \mathrm{t} \\
\text { acture } \\
\text { norma }\end{array}$ & $\begin{array}{l}\text { (TBC } \\
\text { the } \\
\text { em, a } \\
\text { e blad } \\
\text { the r } \\
\text { the b } \\
\text { ralloy } \\
\text { and } \\
\text { ermal } \\
\text { bonc } \\
\text { lure } b \\
\text { separ }\end{array}$ & $\begin{array}{l}\text { are u } \\
\text { agine } \\
\text { shown i } \\
\text { s and cc } \\
\text { etal tem } \\
\text { nding b } \\
\text { and to } \\
\text { ot corr } \\
\text { grown } \\
\text { coat. Tl } \\
\text { tween } \mathrm{t} \\
\text { ion (ve } \\
\end{array}$ & $\begin{array}{l}\text { dely used ir } \\
\text { ades from } \\
\text { the figure, is } \\
\text { sists of a ce } \\
\text { erature; a me } \\
\text { ween the top } \\
\text { also protec } \\
\text { sion. Due t } \\
\text { xide (TGO) } \\
\text { concern in } \\
\text { TC and th } \\
\text { ical) or by }\end{array}$ \\
\hline \multirow[t]{6}{*}{ Problem } & $\begin{array}{l}\text { Consider a TBC } \\
\text { the substrate for } \\
\text { is assumed bet } \\
\text { metallic), and } \\
\text { top coat, TGO } \\
\text { operated under } \\
\text { superalloy has a } \\
\text { the effect of th } \\
\text { indicate if, and } \\
\text { interface betwe } \\
\text { MPa for tensil } \\
\text { Material proper }\end{array}$ & $\begin{array}{l}\text { ystem c } \\
\text { our ana } \\
\text { een the } \\
\text { inusoid } \\
\text { and th } \\
\text { heat flux } \\
\text { emperat } \\
\text { thermal } \\
\text { here, lo } \\
\text { the TC } \\
\text { fractur } \\
\text { s are gi }\end{array}$ & $\begin{array}{l}\text { 50 } \\
\text { sistin } \\
\text { sis as } \\
\text { ond } \\
\text { inter } \\
\text { bond } \\
\text { f } 20 \\
\text { e of } 2 \\
\text { ads o } \\
\text { l frac } \\
\text { and th } \\
\text { and } \\
n \text { in th }\end{array}$ & $\begin{array}{l} \\
\text { of a TC, } \\
\text { the fig } \\
\text { at and } \\
\text { ce is as } \\
\text { oat. Th } \\
/ \mathrm{mm}^{2} \text { at } \\
\mathrm{C} \text { at the } \\
\text { the stre } \\
\text { re failur } \\
\mathrm{BC} \text { (and } \\
0 \mathrm{MPa} \\
\text { table }\end{array}$ & $\begin{array}{l} \\
\text { TGO, BC, an } \\
\text { re. A flat int } \\
\text { he substrate } \\
\text { umed betwee } \\
\text { turbine bla } \\
\text { he surface, ar } \\
\text { oottom. Inves } \\
\text { ses develope } \\
\text { might occur } \\
\text { TGO) fails a } \\
\text { or shear fra }\end{array}$ \\
\hline & Material & $\begin{array}{c}E \\
(\mathrm{GPa}) \\
\end{array}$ & $v$ & $\begin{array}{c}\alpha \\
\left(1 /{ }^{\circ} \mathrm{C}\right) \\
\end{array}$ & $\begin{array}{c}k \\
\left(\mathrm{~W} /\left(\mathrm{m} .{ }^{\circ} \mathrm{C}\right)\right)\end{array}$ \\
\hline & Top coat & 205 & 0.18 & $\begin{array}{l}12 \mathrm{x} \\
10^{-6} \\
\end{array}$ & 2.6 \\
\hline & TGO & 180 & 0.27 & $\begin{array}{c}8.3 \times \\
10^{-6}\end{array}$ & 5.5 \\
\hline & $\begin{array}{l}\text { Bond } \\
\text { coat }\end{array}$ & 150 & 0.30 & $\begin{array}{c}14.3 \\
\times \quad 10^{-6} \\
\end{array}$ & 31.0 \\
\hline & Substrate & 203.4 & 0.35 & $\begin{array}{c}8.6 \times \\
10^{-6} \\
\end{array}$ & 21.9 \\
\hline
\end{tabular}

TABLE V. Samples of students' projects

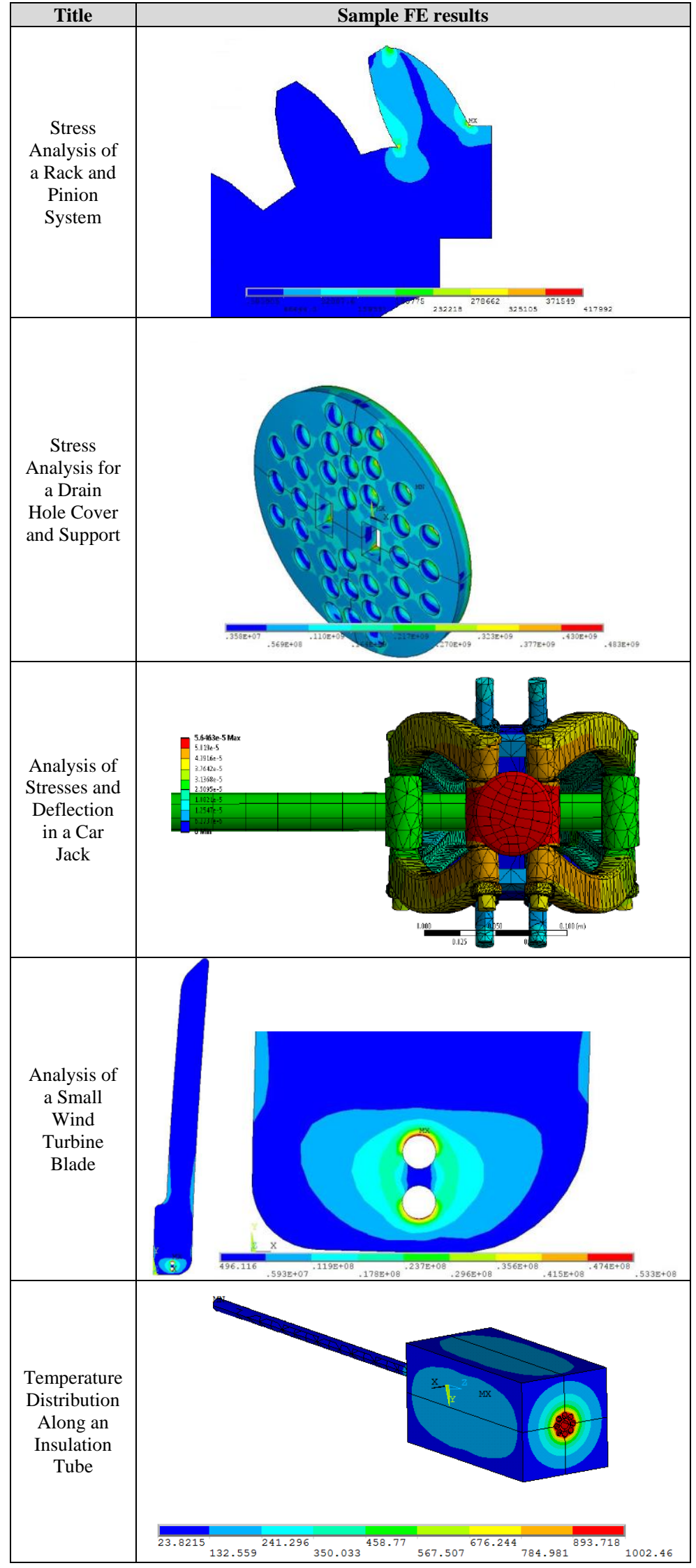




\section{Students' comments}

Students were asked towards the end of the course to submit anonymous feedback regarding the course structure and the way it was taught. It is important to note that most engineering and science courses at KFUPM tend to have two major exams instead of one midterm exam. Also assignments are usually worth between $10-15 \%$ of the overall grade.

- The method of making the homework worth $25 \%$ is a very good approach to make students learn, but the problem is that the students are not used to it. A recommendation that I have is to create a texting group for communications instead of blackboard discussion board which is not convenient.

- This is an effective way of teaching (especially the idea of giving conceptual short exam problems and heavy assignments where students can learn). I suggest teaching the software part should be $50 \%$ or more of the course because I think it is the most important part.

- The instructor changed the way of teaching for this course. He made it more about practicing and thinking. The assignments are the major part of that. I liked it, some did not. Maybe they don't like spending long hours on assignments.

- I suggest having video tutorials as they are much more effective than step by step guidelines for the software solved problems. We can learn listening and watching much better than just reading.

- The theory is lengthy and quite boring, he tried all he can to make it not.

- The teaching philosophy is awesome. He really cares about the students understanding. He teaches in a manner that is tailored to the conceptual understanding of the subject. The only complaint that I have is the difficulty in following in class. This is not because of the teacher, rather because of the nature of the subject. Outside of the class, when I have the ability to turn pages on a book, understanding the material is not a problem

There were other comments but related to topics other than the structure of the course and the link between theory and practice. Overall, students responded well to keeping the lengthy hand calculations for students to solve at home as part of the assignments, while focusing more on the use of an FE software in solving practical engineering problems in the lectures and the lab.

\section{CONCLUSION}

This paper presented a modified approach in teaching undergraduate FEA course with more focus on the practical use of FEA. This was based on offering the course as an elective for senior level students at the mechanical engineering department at King Fahd University of Petroleum \& Minerals.
A list of suggested FE theory topics is listed and discussed. Many of the classical topics were removed as they do not add anything to the practical knowledge needed for the students. Cutting many of the theoretical topics gave more room for the practical side of the course to expand and cover a wider range of practical examples. Around $50 \%$ of the lectures were offered in a PC lab were the lecture would focus on solving an engineering problem.

The assignments are carefully designed to ensure a good link between theory (and hand calculations) and utilization of an FE software. Students can solve the problems using the software, but then would use hand calculations for validation and verification of their results. Projects were left to students to work individually or as groups, and pick a topic of their interest. The topic has to be approved by the instructor to ensure that a substantial FE work can be done in the project. Final exam is where the real outcome of the course is tested. Students are given an actual and relevant engineering problem. They are asked to read a little background to understand the topic. Then they are asked to prepare a report on analyzing the problem from idealization till the discussion of the FE results.

Students' comments at the end of the course were mostly positive as they liked this approach. Most of the negative comments were not related to the course structure or the grading scheme.

\section{ACKNOWLEDGMENT}

The author would like to thank King Fahd University of Petroleum \& Minerals (KFUPM) for their support and providing the needed resources to teach the course in the new suggested format.

\section{REFERENCES}

[1] W. Gilewski, "To Teach or not to Teach Finite Elements: This is a Question", 6th AECEF Symposium in Vilnius, Lithuania, 28-30 May, 2008

[2] S. Zhang, "Integrating Finite Element Analysis into Mechanical Engineering Undergraduate Courses.”, ASEE Annual Conference \& Exposition, 13-17 June, Seattle, USA, 2015.

[3] F.U.A. Shaikh, "Role of commercial software in teaching finite element analysis at undergraduate level: a case study", Engineering Education, $7: 2,2-6,2012$.

[4] Y. Zhuge, and J.E. Mills, "Teaching Finite Element Modelling at the Undergraduate Level: A PBL Approach", Proceedings of the 2009 AaeE Conference, Adelaide, Austrailia, 2009.

[5] A. Hossain, "Teaching an Undergraduate Introductory Finite Element Analysis Course: Successful Implementation for Students Learning", ASME International Mechanical Engineering Congress and Exposition, Volume 5: Education and Globalization, Houston, Texas, USA, November 13-19, 2015, doi:10.1115/IMECE2015-50091.

[6] A.R. Moazed, R. Roberts, Z. Le, A. Duva, "Teaching Finite Element Analysis in Undergraduate Technology Curriculum", ASEE Northeast Section Conference, Wentworth, Institute of Technology, Boston, MA, May 7-8, 2010

[7] K. Al-Athel, K. Loeffel, H. Liu and L. Anand, "Modeling decohesion of a top-coat from a thermally-grown oxide in a thermal barrier coating", Surface \& Coatings Technology, Vol, 222, pp.68-78, 2013. 